\title{
DINAMIKA PEMBANGUNAN MASYARAKAT KUDUS BERKONTEKS SEJARAH INDUSTRI DAN BUDAYA LOKAL
}

\section{Imaniar Purbasari}

\author{
PGSD FKIP Universitas Muria Kudus
}

\begin{abstract}
Positive and negative aspects for developing area by the industrial sector is the one of way to development society. Learn by trading of Kudus community then entered the industrial era an indicator of traditional move to modern community. This research aims to explain the dynamics of developmental community from the industrial sector in Kudus. Now, Kudus community must be brave to openness and ability to adjust the progress by the industry. Observation to get validity of data on the behavior of the people in Kudus. Development community can be seen from society to open and encouraging each people to move utilizing natural commodities very wisely and economy commodity by the environment.
\end{abstract}

Keywords: economic, social, Kudus society

\begin{abstract}
Abstrak
Aspek positif dan negatif terhadap wilayah yang mengembangkan kehidupan dari sektor industri adalah perkembangan kemasyarakatan beraneka ragam. Belajar dari latar belakang dagang masyarakat Kudus kemudian masuk industri merupakan indikator pembangunan masyarakat. Penelitian ini bertujuan mengungkap dan menjelaskan dinamika pembangunan masyarakat Kudus yang tidak dapat lepas dari sektor industri di Kudus. Semakin ke depan dinamika pembangunan masyarakat Kudus menunjukkan keterbukaan dan kemampuan menyesuaikan diri terhadap kemajuan yang diimbaskan oleh industri. Pengamatan terhadap dinamika pembangunan masyarakat Kudus ini dilakukan agar memperoleh keabsahan data terhadap perilaku masyarakat Kudus dalam periode penelitian. Pembangunan masyarakat dapat dilihat dari dinamika dalam masyarakat membuka dan mendorong masing-masing individu untuk bergerak secara bijak memanfaatkan komoditas alam dan komoditas ekonomi di lingkungannya.
\end{abstract}

Katakunci: ekonomi, sosial, masyarakat Kudus 


\section{PENDAHULUAN}

Pembangunan pada dasarnya merupakan suatu perubahan ke arah lebih baik. Pembangunan selama ini lebih dikaitkan dengan pembangunan infrastruktur. Masyarakat sendiri tidak lepas dari fenomena pembangunan, oleh karena itu pembangunan dapat juga berupa pembangunan masyarakat yang beraneka ragam menuju kehidupan modern dan dinamis. Yang dimaksud dengan pembangunan masyarakat yaitu mengkonstruksi masyarakat sebagai masyarakat maju yang menyadari akan kemajuan yang diperolehnya sesuai perkembangan jaman. Proses pembangunan dapat digunakan sebagai alat ukur sejauh mana dapat memenuhi kebutuhan hidup, memecahkan masalah dari dinamika masyarakatnya (Moeis, 2009: 2).

Kudus merupakan daerah industri, keuntungan menjadi sebuah daerah industri tidak hanya sebatas keuntungan ekonomi berupa berkurangnya tingkat pengangguran, menambah mata pencaharian, menambah pendapatan, dan meningkatkan status sosial. Sebuah masyarakat yang maju merupakan masyarakat mampu memanfaatkan pendapatan ekonomi untuk keluar dari zona kenyamanan. Masyarakat Kudus yang sebagian besar merupakan buruh industri pada umumnya merasa stabil dalam kehidupannya karena memperoleh pendapatan tetap, sehingga stagnannya masyarakat Kudus dalam perkembangan kehidupannya sebagai buruh. Masyarakat sudah mampu memanfaatkan potensi ekonominya, sehingga stagnasi masyarakat dapat dikembangkan menuju kedinamisan. Penelitian ini berusaha untuk melacak sejarah terbentuknya masyarakat Kudus dari sektor ekonomi dan sosial, kemudian memotret perkembangan masyarakat Kudus yang mengarah ke pembangunan masyarakat modern, serta mendeskripsikan peran pemerintah dan swasta dalam pembangunan masyarakatnya. 
Peran pemerintah dalam pembangunan identitas masyarakat Kudus yaitu mengelola perekonomian daerah Kudus sebagai masyarakat industri, membangun perekonomian daerah yang sebagian besar dikuasai oleh sektor swasta sehingga berimbas pada pembangunan dan berdampak langsung terhadap kesejahteraan masyarakat. Peran swasta juga tidak kalah penting dalam pembangunan yang harusnya berdampak ekologi terhadap masyarakat sekitar. Penyediaan lapangan kerja, stimulan terbentuknya masyarakat dagang, pemeliharaan lingkungan, edukasi ekonomi, kemudahan akses transportasi dan teknologi, terbentuknya wisata identitas terhadap kota Kudus merupakan imbas pembangunan daerah oleh industri-industri swasta di Kudus.

\section{METODE PENELITIAN}

Penelitian bertujuan mengungkap dan menjelaskan dinamika pembangunan masyarakat Kudus yang tidak dapat lepas dari sektor industri di Kudus yang akhirnya menjadi take line dan etos kerja masyarakat Kudus. Pengumpulan data diperoleh dari hasil observasi dan wawancara terhadap perubahan masyarakat Kudus, serta studi literatur sejarah dan perkembangan masyarakat Kudus. Data tersebut dianalisis meliputi: mereduksi informasi, menyajikan data, dan menyimpulkan temuan. Sehingga diperoleh temuan yang mampu mengungkapkan pembangunan masyarakat Kudus yang dinamis terhadap kemajuan.

\section{HASIL DAN PEMBAHASAN}

\section{Sejarah Masyarakat Kudus}

Kudus merupakan kota pedalaman di utara Jawa Tengah yang berbatasan langsung dengan daerah-daerah dataran rendah. Kudus memiliki 
kontur tanah datar dan berhawa panas (sejuk), sehingga lahan di kota Kudus cocok dimanfaatkan untuk penanaman tanaman pangan. Selain itu, pengaruh agama Islam di Kudus juga memungkinkan munculnya jiwa dagang masyarakat Kudus. Penduduk desa sebagian besar memanfaatkan lahan pertanian dengan bertani tanaman pangan dan tebu. Penduduk di sekitar Kudus Kulon dan Kudus Kota memanfaatkan pengaruh jiwa agama Islam dengan berdagang. Penduduk memegang peranan penting dalam pembangunan, sesuai dengan potensi alam (pemanfaatan lahan) dan potensi sumber daya manusia daerah tersebut.

Penduduk Kudus terdiri dari berbagai macam etnis dan keturunan. Penduduk kota Kudus terdiri dari: pribumi, bangsa Arab, dan etnis Tionghoa. Sebagian besar penduduk Kudus memeluk agama Islam. Kaum Tionghoa sebagian besar tinggal di sekitar pusat kota, seperti di wilayah: Kramat, Panjunan, Wergu, Demaan. Orang-orang keturunan Arab sebagian tinggal di sekitar kompleks Sunan Kudus. Orang-orang pribumi menyebar ke seluruh penjuru kota Kudus. Kebanyakan dari penduduk Kudus dahulunya berprofesi sebagai pedagang, petani, perajin, atau petugas agama. Pedagang pergi membeli maupun menjual dagangannya, menjajakan dagangannya ke berbagai penjuru dan kembali ke daerah asalnya untuk berapa lama dan kemudian melakukan aktivitas dagangnya kembali. Perdagangan merupakan salah satu sumber utama kemakmuran kota Kudus sampai munculnya industri rokok kretek Kudus (Lance Castle, 1982: 82-83).

Pertumbuhan penduduk yang terjadi di Kudus mengakibatkan seluruh aspek masyarakat maupun pemerintah berusaha mengupayakan suatu cara untuk bisa tetap menjamin kesejahteraan masyarakat secara merata. Perubahan dari satu sektor, nantinya akan mempengaruhi sektor-sektor lainnya. Pertumbuhan penduduk wanita secara nyata jumlahnya lebih banyak dibanding dengan jumlah pertumbuhan penduduk laki-laki. Untuk mengatasi pertambahan 
penduduk di wilayah Kudus dan semakin sempitnya lahan pertanian, maka diusahakan satu sektor di luar pertanian yaitu industri. Adanya industrialisasi, terutama industri rokok kretek Kudus membawa kemajuan yang berarti bagi kota Kudus. Di bidang industri, aneka perusahaan rokok kretek mulai dibangun dari usaha kecil. Tercatat 62 perusahaan rokok kretek berkembang di kota Kudus (Solichin Salam, $1983: 8$ ).

Keterkaitan antara pemenuhan kesejahteraan masyarakat dengan penyempitan lahan pertanian, mendorong sebagian penduduk wanita untuk bekerja dalam sektor industri rokok kretek Kudus. Buruh wanita lebih banyak dibutuhkan dalam industri rokok kretek Kudus, karena pengerjaan produksi rokok kretek Kudus memerlukan kesabaran, ketelitian, keuletan, dan kerapian. Upah buruh wanita juga lebih murah jika dibandingkan dengan buruh pria. Industrialisasi mengakibatkan kesejahteraan keluarga dari buruh wanita lebih terjamin, daripada mereka hanya menggantungkan hidupnya dari hasil tani yang tidak memberikan harapan hidup secara pasti (Sofia, 1992: 30).

Kondisi kota Kudus cukup luar biasa dalam beberapa hal. Hampir disepanjang jalan baik di kota maupun di pinggir kota dapat dijumpai pabrik rokok kretek baik besar maupun kecil. Bau saus campuran cengkeh dan tembakau mengisi lapisan udara di sepanjang jalan yang berderet gudang atau brak pabrik rokok kretek. Salah satu fenomena yang menarik di Kudus adalah pada waktu pagi-pagi buta wanita-wanita dari berbagai district di sekitar Kudus beramai-ramai memasuki pintu gerbang pabrik rokok kretek bagaikan arakarakan semut. Kendaraan distribusi rokok kretek terlihat sering melintas menghantarkan kebutuhan konsumen. Pada sore hari mereka berbondongbondong keluar dari brak pabrik rokok tempat mereka bekerja, dan menjalani kebiasaan para ibu-ibu yaitu berbelanja bahan makanan di depan pabrik yang telah siap dijajakan oleh para penjual insidental (Lance Castle, 1982: 72). 
Kudus merupakan daerah industri dan perdagangan, di mana sektor ini mampu menyerap banyak tenaga kerja dan memberikan kontribusi yang besar terhadap PDRB (Produk Domestic Regional Bruto). Jiwa dan semangat wirausaha masyarakat Kudus diakui ulet, semboyan gusjigang (bagus ngaji dagang) yang dimiliki masyarakat mengungkapkan karakter, bahwa dalam menjalankan usaha ekonomi juga menggunakan dasar ilmu agama. Kudus merupakan daerah yang dibentuk oleh Sunan Kudus dengan etos kerja yang baik. Sunan Kudus sendiri merupakan seorang pedagang. Bagi Sunan, orang saleh adalah orang yang menyeimbangkan niat dengan usaha, ibadah menjadi sumber energi dan pendorong gairah kerja. Masyarakat Kudus yang menyimpan jiwa dagang dan etos kerja tinggi mampu mandiri di bidang perekonomian. Etos kerja yang tinggi muncul akibat adanya berbagai tantangan dan harapan. Kerja keras yang tekun merupakan jawaban waktu terhadap kesuksesan pengusaha industri rokok kretek (Suharso, 1994: 154-155).

Kudus tergolong unggul dalam bidang industri, pabrik gula terdapat di pinggir kota, pabrik kertas terdapat di berbagai penjuru, dan hampir di setiap jalan di kota Kudus rupanya terdapat pabrik kretek besar ataupun kecil. Orangorang Kudus dahulunya memang terkenal dengan kehidupannya yang tidak jauh bergelut dengan perdagangan dan industri kecil. Pekerjaan sebagai pedagang menjadikan orang-orang Kudus terbiasa mengadakan usaha ke daerah-daerah lain untuk menguatkan jaringan distribusi hasil produksinya, termasuk rokok kretek. Selama abad ke-19 Kudus menjadi pusat sejenis perdagangan khas, pedagang menjajakan barang dagangannya ke berbagai penjuru, kembali ke kota Kudus sementara waktu, dan kemudian menjalani aktivitas berdagang kembali ke berbagai wilayah. Modal yang rendah, transaksi perdagangan minim, dan munculnya saingan pedagang Cina mengakibatkan pedagang pribumi harus pandai-pandai menyiasati persaingan perdagangan. 


\section{Pembangunan Masyarakat Kudus}

Pembangunan masyarakat adalah suatu proses melalui usaha dan prakarsa masyarakat sendiri maupun kegiatan pemerintahan dalam rangka memperbaiki kondisi ekonomi, sosial dan budaya (Suharyanto, 2006: 3). Usaha pengembangan masyarakat merupakan salah satu proses untuk mengubah manusia dan lingkungan sekitarnya ke arah yang lebih baik. Untuk mencapai kondisi yang diharapkan, sangat dibutuhkan tenaga-tenaga khusus yang bersifat sebagai pembaharu (agent of change).

Potensi ekonomi Kabupaten Kudus terdiri dari sumber daya manusia, sumber daya alam dan sumber daya buatan, serta kondisi geografis yang mendukung menjadikan Kudus sebagai wilayah yang berpotensi tinggi mengembangkan sistem industri terutama industri rokok kretek, industri kertas, dan industri tebu. Untuk dapat memanfaatkannya maka diperlukan perencanaan, inovasi dari sumber daya manusianya, serta dukungan dari aspek ekonomi agar pengembangan kota Kudus sesuai dengan kondisi masyarakatnya. Sejak ditemukan rokok kretek Kudus dan berkembangnya industri rokok kretek Kudus, potensi ekonomi baik itu sumber daya manusia, sumber daya alam dan sumber daya buatan di daerah Kudus serta sumber daya dari daerah luar penghasil bahan baku rokok kretek Kudus dapat dimanfaatkan dengan efektif.

Namun, pembangunan masyarakat sering kali hanya diidentikkan dengan peningkatan taraf ekonomi. Sarana dan prasarana yang memadai untuk kehidupan orang modern, juga tingkat hidup yang mencirikan kehidupan orang modern dalam hal ini pembangunan masyarakat dianggap sebagai sebuah hal yang dangkal. Masyarakat Kudus terbentuk sebagian besar merupakan masyarakat buruh pabrik industri. Bukan berarti apabila masyarakat industri yang terbentuk maka masyarakat yang ada berubah menjadi masyarakat 
berorientasi menjadi buruh hanya menghasilkan ekonomi/keuangan yang terbuai dengan stagnasi dan berada pada zona nyaman. Seharusnya masyarakat Kudus yang terbentuk merupakan masyarakat dinamis yang berkembang menuju masyarakat modern yang mampu mengikuti perkembangan jaman baik dalam orientasi kehidupan, pemahaman akan pendidikan, teknologi, dan seni, serta kemajuan pola pikir dinamis bukan statis. Secara ekonomis masyarakat Kudus merupakan masyarakat dengan status sosial menengah akibat adanya berbagai perusahaan industri. Kegiatan ekonomi inilah yang harusnya menciptakan agent of change. Agent of Change dalam hal ini merupakan masyakat buruh Kudus sendiri dalam memanfaatkan kondisi dan kompetensi kota Kudus ke arah kemajuan berupa kedinamisan kehidupan sosial dan kehidupan ekonomi masyarakat Kudus. Butuh sebuah kondisi persaingan atau kondisi kompetitif untuk menghidupkan ketenangan masyarakat Kudus yang terbuai dengan zona nyaman, sehingga perlu peran pemerintah dan swasta dalam kepedulian pembangunan masyarakat Kudus.

Pemda memfasilitasi masyarakat melalui APBD daerah untuk mengembangkan masyarakat Kudus yang dinamis. Otonomi daerah yang diterapkan melalui desentralisasi fiskal merupakan instrumen yang dikelola pemerintah untuk mengelola pembangunan sehingga guna mendorong perekonomian pusat dan daerah. Desentralisasi akan membawa kemudahan terhadap daerah untuk membangun perekonomian yang akan berimbas pada pembangunan sehingga berdampak pada kesejahteraan masyarakat. Dari segi pendapatan dan belanja merupakan kewajiban dan hak dari masyarakat. Pemda hendaknya menggunakan pendapatan untuk belanja sebagai upaya pembangunan yang tepat sasaran dan menjawab kebutuhan masyarakat. Pengelolaan otonomi fiskal memberi kebebasan sesuai dengan kebutuhan dan 
prioritas masing-masing. Harapannya percepatan pembangunan untuk peningkatan kesejahteraan masyarakat terwujud (Noor, 2012: 7-8).

Pabrik rokok kretek Kudus merupakan sumber pendapatan pajak terpenting bagi pemerintah. Berbagai macam pajak bisa ditarik dari industri rokok kretek, mulai dari cukai tembakau, pajak perseroan, pajak reklame, dan sebagainya. Pajak yang dibayarkan oleh pabrik rokok kretek Kudus sangat besar jumlahnya dan sangat berarti bagi pembangunan bangsa dan negara. Pabrik rokok kretek Kudus juga melakukan berbagai macam usaha secara mandiri demi pembangunan daerah dan pusat. Penerimaan pemerintah daerah untuk pemanfaatan pembangunan masyarakat Kota Kudus merupakan kewajiban yang harus dilaksanakan dalam membangun masyarakat Kudus yang dinamis. Pemerintah mendukung dan menstimulus kondisi dinamis dengan menciptakan persaingan ekonomi dari kemapanan ekonomi masyarakat Kudus. Melalui pendidikan, pertanian, perdagangan, jasa yang mampu dimanfaatkan dari potensi dan peluang yang ada di Kota Kudus dapat digunakan untuk mendorong kondisi ekonomi kompetitif, yang menjadikan buruh industri sebagai masyarakat yang maju dan dinamis.

Kehadiran pabrik rokok kretek di Kudus membawa perubahan dalam kehidupan ekonomi masyarakat. Dengan adanya perubahan ekonomi yang makin baik, menyebabkan masyarakat mempunyai perhatian terhadap pendidikan. Semakin meningkatnya status ekonomi orang tua mereka menunjukkan semakin tingginya kesadaran bahwa pendidikan menjamin seseorang agar lebih terjamin peningkatan taraf hidupnya. Setelah masyarakat Kudus banyak yang berpendidikan maka pabrik rokok kretek Kuduspun mempekerjakan buruh yang berpendidikan.

Ekonomi daerahnya maju, maka muncul pedagang yang menawarkan barang penunjang usaha pertanian, barang elektronik, bahan bangunan dan 
sebagainya. Adanya listrik masuk desa, karena perusahaan rokok kretek Kudus banyak yang mendirikan gudang penyimpanan tembakau di wilayah pedesaan. Sarana kesehatan dan fasilitas keagamaan semakin diperhatikan dan ditingkatkan.

Pembangunan daerah Kudus, yang dilakukan pabrik rokok kretek Kudus antara lain sektor kesehatan dan peribadatan yang sebagian besar bernaung di bawah yayasan kesehatan yang dikelola oleh pihak swasta. Kehadiran pabrik rokok kretek Kudus memberikan dampak positif terhadap pembangunan fisik kota Kudus. Pemerintah memperoleh keuntungan besar dengan adanya perusahaan rokok kretek. Adanya pajak cukai, menjadikan pemasukan besar bagi pemerintah pusat. Pembangunan daerah juga tercukupi, pemasukan terhadap pemerintah daerah juga ada. Partisipasi pengusaha rokok kretek dapat dilihat dari sumbangan-sumbangan di lingkungan sekitar lokasi tempat perusahaan berada. Lampu jalan di sekitar kota Kudus, penghijauan kota Kudus, pembangunan infrastruktur modern, bantuan pendidikan, bantuan terhadap olahraga, pagelaran musik, dan sebagainya merupakan andil besar swasta termasuk pabrik-pabrik rokok kretek Kudus dalam memajukan kualitas bangsa.

Swasta tidak hanya memfasilitasi infrastruktur daerah namun juga membangun masyarakatnya, sehingga yang terjadi adalah pembangunan seutuhnya. Pembangunan sebuah daerah industri akan berdampak pada pembentukan masyarakat industri yang dinamis. Bantuan sport, lingkungan, pendidikan merupakan bentuk kepedulian swasta dan kewajiban swasta dalam etika dan aturan industri. Bantuan tersebut kurang satu kajian yaitu membentuk masyarakat yang berorientasi pada kehidupan dinamis melalui inovasi tidak mengandalkan zona nyaman berupaya kemajuan kehidupan menuju pemanfaatan ekonomi dan persaingan ekonomi. 
Jiwa dagang dan industri yang dibangun sejak masa lampau hingga saat ini merupakan salah satu wujud budaya lokal masyarakat Kudus. Membahas budaya lokal, secara pengertian luas dikatakan oleh Judistira (2008:113) bahwa budaya lokal bukan hanya terungkap dari bentuk dan pernyataan rasa keindahan melalui kesenian belaka; tetapi termasuk segala bentuk, dan cara-cara berperilaku, bertindak, serta pola pikiran yang berada jauh di belakang apa yang tampak tersebut. Perwujudan budaya lokal terdapat pada tradisi, religi, sosial, teknologi dan seni.

Industrialisasi di kota Kudus memberikan model pelestarian budaya lokal di bidang ekonomi dan sosial kemasyarakatan. Salah satu usaha untuk melestarikan budaya lokal melalui industrialisasi dilakukan dengan memberikan pemahaman tentang hasil-hasil budaya setempat kepada generasi penerus. Karakter masyarakat dagang dan industri, keseharian masyarakat industri, hasil industri dan pencirinya berfungsi untuk menanamkan nilai (value) serta membangun karakter (Character Building) masyarakat dari generasi ke generasi secara berkelanjutan dan berkesinambungan.

\section{SIMPULAN}

Bangsa Indonesia tidak bisa luput dari fenomena pembangunan, cepat atau lambat, besar atau kecil, mudah atau sukar, proses pembangunan ini perlu untuk dilakukan. Berbagai cara untuk mencapainya diupayakan, yaitu dengan pemanfaatan secara optimal segala aspek sumber daya manusia dan sumber daya alam yang ada, sehingga mempunyai peran penting dalam lingkup lokal maupun global. Terjadinya pembangunan masyarakat dapat dilihat dari dinamika dalam masyarakat membuka dan mendorong masing-masing individu untuk bergerak menjadi masyarakat berjati diri lokal dan saling bergerak secara bijak memanfaatkan komoditas alam dan komoditas ekonominya. 


\section{DAFTAR PUSTAKA}

IsranNoor. 2012. Politik Otonomi Daerah. Jakarta: Seven Strategies Studies.

Judistira K. Garna. 2008. Budaya Sunda : Melintasi Waktu Menantang Masa Depan. Bandung : Lemlit Unpad.

Lance Castle. 1982. Tingkah Laku Agama, Politik dan Ekonomi di Jawa : Industri Rokok Kudus. Jakarta : Sinar Harapan.

Sofia. 1992. Perkembangan Buruh Rokok PT Djarum Kudus 1955-1965. Semarang: UNDIP.

SolichinSalam. 1983. Kudus dan Sejarah Rokok Kretek. Kudus : PPRK.

Suharso. 1994. Masyarakat Kudus Kulon dalam Pembangunan Ekonomi. Jakarta : IKIP Jakarta.

SyarifMoeis. 2009. Pembangunan Masyarakat Indonesia Menurut Pendekatan Teori Modernisasi dan Teori Dependensi. Bandung: UPI. 